\title{
Winter bird numbers and land-use preferences in an arable landscape in eastern England
}

\author{
CHRISTOPHER F. MASON and SHEILA M. MACDONALD
}

\section{Summary}

The winter bird assemblage and habitat preferences were studied in a largely arable landscape, dominated by winter cereals, in eastern England in one winter. A total of 32 species was recorded on $701-\mathrm{km}$ transects but $11 \%$ of transects had no birds. Overall densities were low, Skylark Alauda arvensis being the most abundant species. Bird density was highest in the first winter period (October-December). Species richness varied in proportion to the available habitat in the first winter period but there was a preference for stubble, grass and tilled land (harrow) in the second winter period (January-February). Skylarks preferred stubbles in the first winter period and stubbles and grass in the second winter period. Some $34 \%$ of all birds fed on winter cereals despite a lack of preference for this habitat, while $94 \%$ of seed specialists (finches and buntings) were recorded on stubbles. The areas of preferred habitats (stubbles, grass) were probably too limited to allow more than small populations to persist. Only by the widespread adoption of agricultural extensification and/or farming some of the land specifically for conservation benefits can the declines in bird populations on intensively managed arable farmland be reversed.

\section{Introduction}

The populations of many bird species breeding on farmland in Britain have shown large decreases over the past 30 years (Fuller et al. 1995). These declines have been linked to the intensification of agriculture, with increases in the use of pesticides and herbicides removing much of the potential food supply of birds, both invertebrates and plants (Pain and Pienkowski 1997, Donald 1998). There has also been a large-scale shift from mixed farming to intensive arable agriculture during the period, and from mainly spring-sown crops to those sown in autumn. This not only affects birds during the breeding season (e.g. Wilson et al. 1997) but it may also influence winter survival because it results in a large decline in the availability of stubbles and bare ground which offer greater feeding opportunities for birds than cereal monocultures (Wilson et al. 1996).

Despite these widespread declines, there have been very few studies of bird populations and habitat preferences of birds on farmland in winter. These include a few single species studies, for example of Lapwing Vanellus vanellus and Golden Plover Pluvialis apricaria (Mason and Macdonald 1999 and references therein), Corn Bunting Miliaria calandra (Donald and Evans 1994), Cirl Bunting (Evans and Smith 1994) and Skylark Alauda arvensis (Wakeham-Dawson and 
Aebischer 1998) but only Tucker (1992) and Wilson et al. (1996) have reported more general studies on the winter use of farmland by assemblages of birds. Both studies recommend further work to evaluate the generalities of their findings.

The present study examined the relative abundance and habitat preferences of birds feeding on farmland during winter in a largely arable landscape in eastern England. The area was typical of the region in having a much larger area under winter cereals than in the study areas of Tucker (1992) and Wilson et al. (1996).

\section{Study area and methods}

The study was carried out in the Tendring district of north-east Essex, eastern England, U.K. $\left(51^{\circ} 50^{\prime} \mathrm{N}, 1^{\circ} 10^{\prime} \mathrm{E}\right)$, a peninsula of area $325 \mathrm{~km}^{2}$. It is bounded by the Stour estuary to the north, the Colne estuary to the south and the North Sea to the east. The climate is more continental than in most of England, with a low annual rainfall (average $510 \mathrm{~mm}$ ), much of it falling in summer, higher summer temperatures and colder winters than average. The agriculture is predominantly arable, occupying $63 \%$ of the area. There is an additional $13 \%$ grassland. The built-up environment (towns, villages) occupies $14 \%$ of the area, the remainder being woodland and minor habitats (wasteland, water, etc.).

Forty transects of length $1000 \mathrm{~m}$ were selected randomly and surveyed between October and December 1997 (first period). A further 30 transects were surveyed in January and February 1998 (second period). Transects were more or less straight tracks or footpaths crossing farmland but away from the immediate environs of hedgerows, woods etc. Each transect was walked slowly and all birds within $100 \mathrm{~m}$ either side of the transect were noted, as was the land-use with which they were associated. On the return walk birds were again counted and the area under each land-use estimated (i.e. the length in metres along the transect and length in metres at right angles to the transect). Land-use categories were cereal stubble (the remains of the previous summer's harvest), plough (bare ground, still in furrow), harrow (bare earth with a fine tilth, ready for seeding) or individual crop types, including grass. The number of each species present on each transect was taken as the sum of the highest count of individuals in each land-use section on the outward and return journey. All surveys were conducted in the morning and wet and/or windy weather was avoided.

\section{Results}

The proportions of transects under the different land-uses in the first (OctoberDecember) and second (January-February) winter periods are given in Table 1. Of the grassland, $60 \%$ was grazed ( $49 \%$ by horses, $51 \%$ by cattle), while $21 \%$ of the ungrazed grassland was classed as amenity grassland. There was a significant difference in the proportion of the study area under the various land-uses between the two periods $\left(\chi^{2}=32.9, d f=5, P<0.001\right)$. Stubble and harrow decreased in the second period and the amount of plough and winter cereal increased.

A total of 32 species was recorded, 28 in the first period and 22 in the second period. The species richness in the transects was examined. Eight transects (11\%) held no birds at all, the maximum number of species on a transect being 
Table 1. Percentage of transects under different land-uses in the two winter periods

\begin{tabular}{lcc}
\hline Land-use & $\begin{array}{c}\text { First period } \\
\text { (October-December) }\end{array}$ & $\begin{array}{c}\text { Second period } \\
\text { (January-February) }\end{array}$ \\
\hline Stubble & 19.6 & 3.5 \\
Plough & 7.2 & 23.5 \\
Harrow & 14.8 & 2.8 \\
Winter cereal & 34.7 & 50.0 \\
Sugar beet & 3.7 & 1.2 \\
Oilseed rape & 8.8 & 4.0 \\
Other arable crops & 2.7 & 4.3 \\
Grass & 8.1 & 9.7 \\
\hline
\end{tabular}

nine. There was no significant difference in species richness between the two periods $\left(\chi^{2}=3.5, d f=2, \mathrm{~ns}\right)$ so data were combined (Figure 1 ). The majority of transects held three species or less.

Significantly more transects held more than 30 individual birds (all species combined) in the first period $\left(\chi^{2}=3.9, \mathrm{df}=1, P<0.05\right), 43 \%$ of all transects holding a total of less than 10 birds (Figure 2). There was no significant difference ( $t$-tests on $\log n+1$ transformed data) between the two periods in the mean densities of individual species on transects so the data were combined. Table 2 presents for individual species the mean densities (calculated on transformed $n+1$ counts), range of counts and percentage of transects in which they were recorded. Only 12 species occurred in 10\% or more of transects. Skylarks were the most widespread and abundant species on transects but even with this species flock sizes were small (Figure 3), the majority being of 10 individuals or less. The total bird density averaged 14 individuals per transect.

The species richness in relation to different land-uses was examined. In the first winter period species richness was distributed in proportion to the area under the various land-uses $\left(\chi^{2}=2.84, \mathrm{df}=6, \mathrm{~ns}\right)$, i.e. there were no marked preferences. In the second winter period there was a significant difference $\left(\chi^{2}=16.1\right.$,

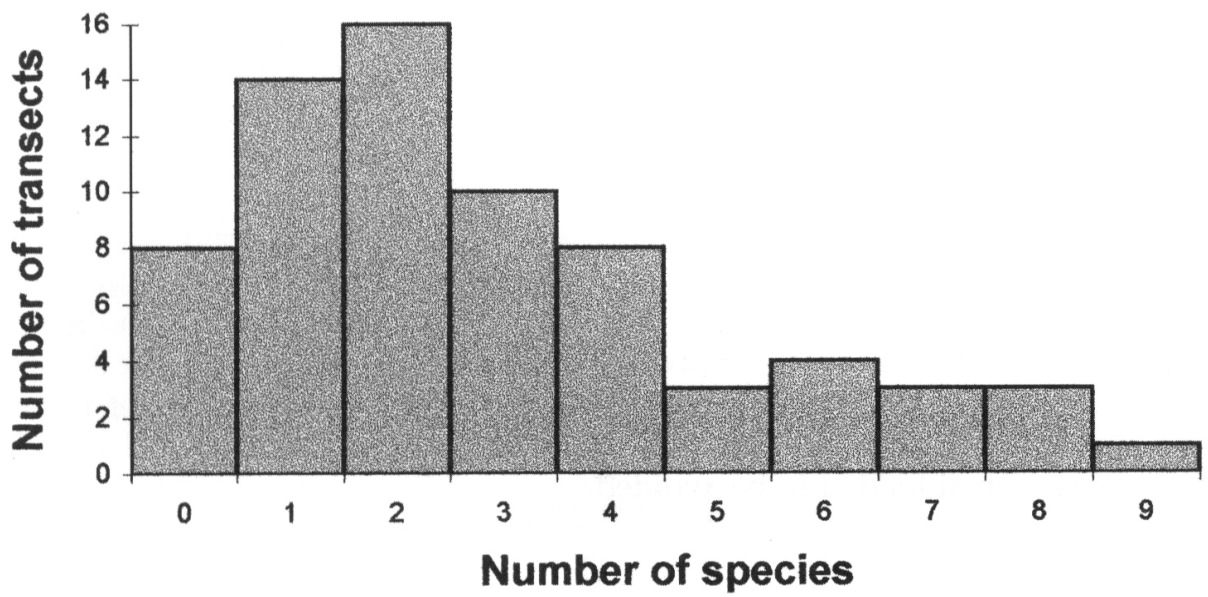

Figure 1 . Species richness in $701-\mathrm{km}$ transects of $200 \mathrm{~m}$ width across farmland in eastern England in winter $1987 / 88$. 


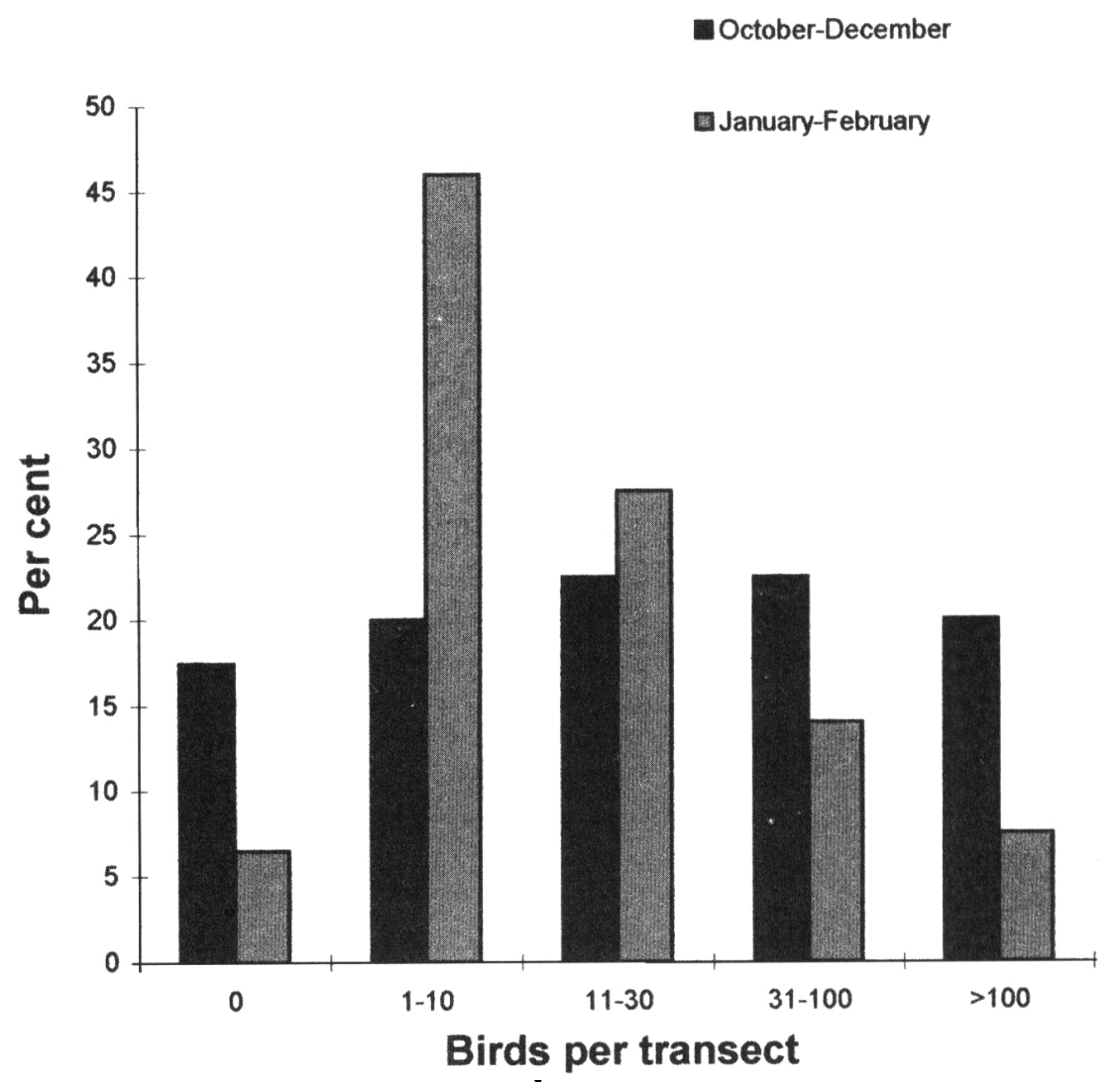

Figure 2. Frequency distribution of total numbers of bird on $1-\mathrm{km}$ transects of $200 \mathrm{~m}$ width across farmland in eastern England in (a) October-December 1997 and (b) JanuaryFebruary 1998.

$d f=4, P<0.001)$. More species than expected were using grass and fewer using winter cereals. Preferences for different land-uses were also examined using Jacobs (1974) preference index $(D)$ :

$$
D=(r-p) /(r+p-2 r p)
$$

where $r$ is the species richness in a land-use category as a proportion of the sum of the species richness over all land-use categories and $p$ is the area of the landuse as a proportion of the total area. The results are given in Table 3 . In the first winter period, there was no clear preference for any land-use shown by the species assemblage, apart from a slight preference for harrow but stronger preferences were shown in the second winter period for grass, harrow and stubble, while winter cereal tended to be avoided.

Jacobs $D$ was also used to determine land-use preferences of individual species occurring in $10 \%$ or more of transects. The results for Skylark, the most widespread species, are given in Table 4 . There was a strong preference for stubble in both winter periods, with a preference also for grass in the second winter period. 
Table 2. Densities of species occurring in $10 \%$ or more of transects

\begin{tabular}{lccc}
\hline Species & $\begin{array}{c}\text { Percentage of } \\
\text { transects }\end{array}$ & $\begin{array}{c}\text { Mean density } \\
\text { per transect }\end{array}$ & Range \\
\hline Skylark Alauda arvensis & 60.0 & 2.74 & $0-70$ \\
Pheasant Phasianus colchicus & 20.0 & 0.20 & $0-8$ \\
Woodpigeon Columba palumbus & 18.6 & 0.48 & $0-48$ \\
Common Gull Larus canus & 18.6 & 0.44 & $0-24$ \\
Carrion Crow Corvus corone & 17.1 & 0.20 & $0-4$ \\
Corn Bunting Miliaria calandra & 14.3 & 0.23 & $0-32$ \\
Lapwing Vanellus vanellus & 12.9 & 0.49 & $0-143$ \\
Red-legged Partridge Alectoris rufa & 12.9 & 0.25 & $0-20$ \\
Starling Sturnus vulgaris & 12.9 & 0.41 & $0-150$ \\
Black-headed Gull Larus ridibundus & 11.4 & 0.31 & $0-47$ \\
Curlew Numenitus arquata & 10.0 & 0.21 & $0-22$ \\
Meadow Pipit Anthus pratensis & 10.0 & 0.22 & $0-42$ \\
Total & 88.4 & 14.04 & $0-317$ \\
\hline
\end{tabular}

Included in the above total (in parentheses: number of transects in which recorded, mean and maximum number per transect): Grey Heron Ardea cinerea $(2,0.02,1)$, Kestrel Falco tinunculus $(2,0.02,1)$, Grey Partridge Perdix perdix (1, 0.02, 2), Moorhen Gallinula chloropus $(1,0.03,5)$, Golden Plover Pluvialis apricaria $(5,0.19,136)$, Lesser Black-backed Gull Larus fuscus $(1,0.02,4)$, Stock Dove Columba oenas (5, 0.09, 4), Pied Wagtail Motacilla alba (3,0.10, 30), Northern Wheatear Oenanthe oenanthe (1, $0.01,1)$, Fieldfare Turdus pilaris (1, 0.08, 18), Song Thrush Turdus philomelos $(1,0.01,1)$, Redwing Turdus iliacus (1, 0.02, 4), Mistle Thrush Turdus viscivorus (1, 0.02, 2), Magpie Pica pica (5, 0.06, 2), Jackdaw Corvus monedula $(6,0.25,35)$, Rook Corvus frugilegus $(6,0.20,53)$, Chaffinch Fringilla coelebs (2, $0.03,2)$, Greenfinch Carduelis chloris $(1,0.06,53)$, Linnet Carduelis cannabina $(1,0.07,54)$, Yellowhammer Emberiza citrinella $(1,0.03,6)$.

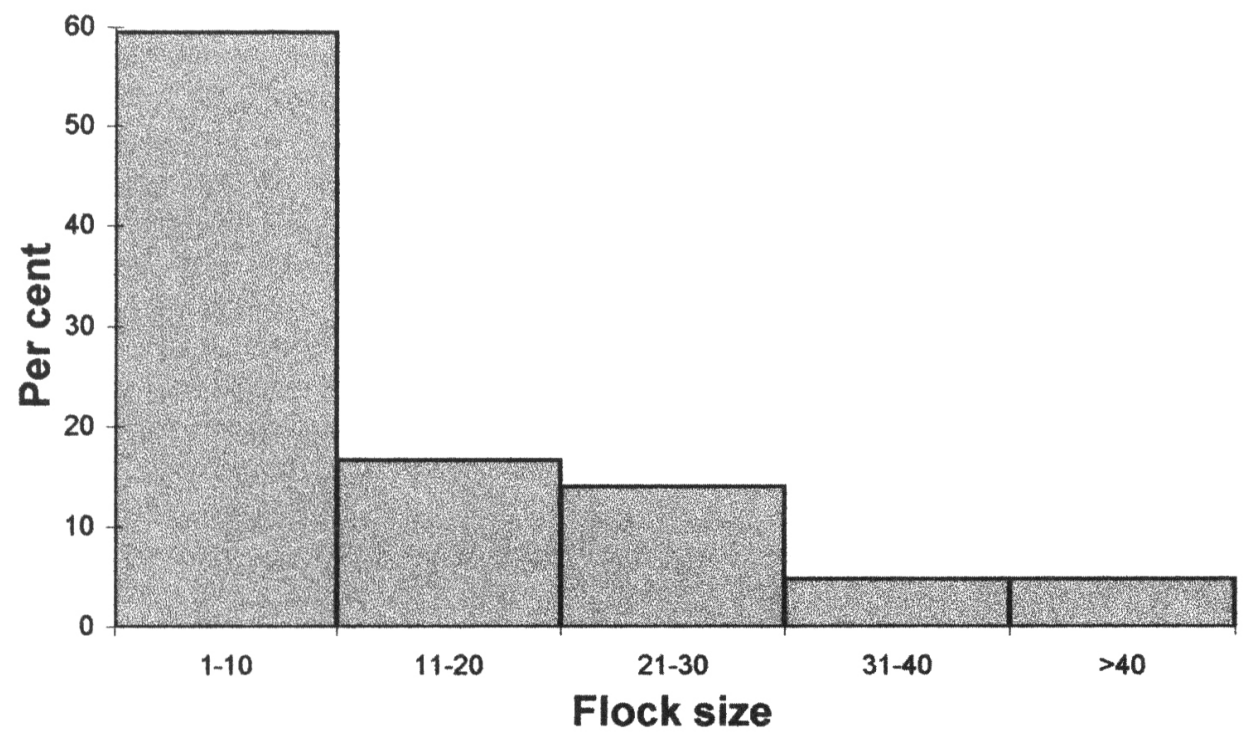

Figure 3. Percentage frequency of flock sizes of Skylarks. 
Table 3. Preferences (Jacobs $D$ ) for different land-uses shown by the species assemblage

\begin{tabular}{|c|c|c|}
\hline Land-use & First winter period & Second winter period \\
\hline Stubble & +0.01 & +0.33 \\
\hline Plough & -0.01 & +0.10 \\
\hline Harrow & +0.21 & +0.42 \\
\hline Winter cereal & -0.08 & -0.29 \\
\hline Sugar beet & -0.11 & NP \\
\hline Oilseed rape & +0.01 & +0.05 \\
\hline Grass & +0.14 & +0.54 \\
\hline
\end{tabular}

NP, not present.

Table 4. Preferences (Jacobs $D$ ) shown by Skylark for different land-uses

\begin{tabular}{lcc}
\hline Land-use & First winter period & Second winter period \\
\hline Stubble & +0.64 & +0.66 \\
Plough & -1.00 & +0.01 \\
Harrow & -0.27 & -0.48 \\
Winter cereal & -0.25 & -0.34 \\
Sugar beet & +0.16 & $\mathrm{NP}$ \\
Oilseed rape & +0.12 & -0.34 \\
Grass & -0.78 & +0.37 \\
\hline
\end{tabular}

NP, not present.

The scarcity or aggregated distribution of the other species allowed only an indication of preferences to be given. Those showing values of $D$ greater than +o.50 were Lapwing (grass, +o.62), Curlew Numenius arquata (grass, +0.92), Common Gull Larus canus (harrow, +o.57), Black-headed Gull Larus ridibundus (harrow, +o.76), Pheasant Phasianus colchicus (stubble, +o.62; sugar beet +0.74 ), Red-legged Partridge Alectoris rufa (oilseed rape, +o.77), Woodpigeon Columba palumbus (plough, +0.53 , with $73 \%$ of birds feeding on bare ground, i.e. plough and harrow), Meadow Pipit Anthus pratensis (stubble, +0.77), Carrion Crow Corous corone (harrow, +o.69), Starling Sturnus vulgare (grass, +o.53) and Corn Bunting (stubble, +o.81; sugar beet, +o.88). Of these 12 species for which preference indices were calculated, none showed a strong preference for the dominant land-use, winter cereals, and eight showed avoidance, two of them strongly (Woodpigeon, -0.90; Corn Bunting, -0.88).

Despite this lack of preference for winter cereals, $37 \%$ of all birds were feeding on this crop. This total included $46 \%$ of all birds considered as invertebrate feeders (following Wilson et al. 1996), only $16 \%$ of which were on grass. Of the seedeaters $18 \%$ were recorded on winter cereals, of which the majority (15\%) comprised Skylarks, known to feed on cereal leaves; $96 \%$ of finches and buntings were feeding on stubbles.

\section{Discussion}

This study was concerned with birds feeding within fields and did not include other habitats within the farmed landscape, especially hedgerows. We would have under-recorded those species which feed along field edges and which do not venture far into fields. The hedgerow density within the study area is rather 
low, with an average of $37.2 \mathrm{~m} \mathrm{ha}^{-1}$ in a survey of 10 tetrads (Mason 1998), about half that considered necessary to support a high density and diversity of birds (Lack 1992). In this study no birds were recorded on eight transects (11\%). It is possible to walk for several kilometres on footpaths through farmland in this district and not record a single bird other than over-flying gulls, especially in the second half of the winter (pers. obs.).

By mid-winter, $50 \%$ of the study area was under conventional winter cereals. By contrast, in south-central England the study area of Tucker (1992) had 29\% winter cereal and that of Wilson et al. (1996) some $26 \%$ conventional winter cereal, with a further $14 \%$ grown organically. Tucker (1992) recorded $12.4 \%$ of stubbles and Wilson et al. (1996) some $14 \%$ in the second half of the winter, compared with $3.5 \%$ in the second winter period in our study area. There are similar differences in grassland area, with Tucker (1992) reporting 34\%, the majority of it permanent grazing and Wilson et al. (1996) some $38 \%$, more than half of it grazed. In contrast, our study area had only 8-9\% grass, $60 \%$ of it grazed but half of it by horses kept for recreational purposes. Our study area represents an extreme in intensification of cereal agriculture.

The overall minimum density of birds on the transects was $70 \mathrm{~km}^{-2}$, assuming that all birds were recorded in the $100 \mathrm{~m}$ on either side of the transect line. In this open landscape we believe that most birds were recorded, except in the small area of broad-leaved crops. There are few published data on densities of birds on farmland in England in winter with which to compare these results. Wakeham-Dawson and Aebischer (1998) recorded Skylark densities on stubbles in southern England of $186-287 \mathrm{~km}^{-2}$, compared with 61 and $129 \mathrm{~km}^{-2}$ in the first and second winter periods in the current study. Conversely the density of Skylarks in winter cereals in the present study was 34.2 and $19.3 \mathrm{~km}^{-2}$ in the first and second winter periods respectively, compared with $1-8 \mathrm{~km}^{-2}$ in the study of Wakeham-Dawson and Aebischer (1998). The lower density in stubbles in our Essex study area suggests that there is just too little suitable habitat for successful foraging to enable birds to remain through the winter.

Tucker (1992) and Wilson et al. (1996) found that grass was the preferred habitat of invertebrate feeding birds, it having the highest densities of invertebrates. Tucker (1992) found no temporal change in preference for grass, in contrast to the present study, where preferences shown by the bird assemblage only became marked in the second winter period. In young cereal crops in the first winter period there may be feeding opportunities in the exposed soil between the plants. Shrubb (1988) found that Lapwings used cereals more in the early winter, switching to grass later, as was found also for this species in the current study area in north-east Essex, where Lapwings deserted the crop when the sward became too tall (Mason and Macdonald 1999). This may be true of other species too, for only $24 \%$ of Skylarks were found in winter cereals in the second winter period, compared with $33 \%$ in the first winter period. Despite a lack of preference for winter cereals, $37 \%$ of birds overall were foraging in this crop, including three times as many invertebrate feeders as were found on grassland. This may again reflect necessity caused by the overall shortage of preferred habitat.

Wilson et al. (1996) found stubble to be the preferred habitat for seed-eating species. The strong preference for cereal stubbles shown by Corn Buntings and Skylarks in the present study was also shown by Donald and Evans (1994) and 
Wakeham-Dawson and Aebischer (1998). Wilson et al. (1996) recorded 88\% of finches, buntings and sparrows (feeding wholly on seeds) on stubbles, compared with $96 \%$ in our study. Indeed, of these seed specialists, we recorded only Corn Buntings on our transects in the second winter period when the proportion of stubbles had fallen to $3.5 \%$; some male Corn Buntings hold territories throughout the winter (pers. obs.).

In conclusion, our farmland study area in north-east Essex held very low numbers of birds. The results support the suggestion of Wilson et al. (1996) that arable farms in eastern England, which have few or no over-winter stubbles, are likely to support few birds except those such as Skylarks which can subsist on green plant material. Even these birds were few. To reverse the rapid declines in bird populations that have occurred in lowland farmland in Britain, and indeed across much of Western Europe, two approaches have been suggested (Evans 1997). First, a reduction in inputs (extensification), which should result in an increase in diversity and quality of available habitat. A move towards a more sustainable agriculture can maintain or even increase farm profitability (Pretty 1998) but it may take some time for such an approach to gain acceptability within political and farming communities. Second, farmers could receive financial support for managing a proportion of their land in a way that produces measurable conservation benefits. For winter birds this could include leaving stubbles over winter and the sowing of set-aside to introduce grassland into exclusively arable landscapes, both increasing foraging opportunities for birds in winter. The results of our study would indicate that either or both of these approaches would have to be undertaken on a wide scale to benefit winter bird populations on arable farmland in eastern England.

\section{References}

Donald, P. F. (1998) Changes in the abundance of invertebrates and plants on British farmland. Brit. Wildlife 9: 279-289.

Donald, P. F. and Evans, A. D. (1994) Habitat selection by Corn Buntings Miliaria calandra in winter. Bird Study 41: 199-210.

Evans, A. (1997) The importance of mixed farming for seed-eating birds in the UK. Pp. 331-357 in D. J. Pain and M. W. Pienkowski, eds. Farming and birds in Europe. San Diego: Academic Press.

Evans, A. D. and Smith, K. W. (1994) Habitat selection of Cirl Buntings Emberiza cirlus wintering in Britain. Bird Study 41: 81-87.

Fuller, R. J., Gregory, R. D., Gibbons, D. W., Marchant, J. H., Wilson, J. D., Baillie, S. R. and Carter, N. (1995) Population declines and range contractions among lowland farmland birds in Britain. Conserv. Biol. 9: 1424-1441.

Jacobs, J (1974) Quantitative measurement of food selection. Oecologia 14: 413-417.

Lack, P. (1992) Birds on lowland farms. London: H.M.S.O.

Mason, C. F. (1998) Habitats of song thrush Turdus philomelos in a largely arable landscape. J. Zool. Lond. 244: 89-93.

Mason, C. F. and Macdonald, S. M. (1999) Habitat use by Lapwings and Golden Plovers in a largely arable landscape. Bird Study 46: 89-99.

Pain, D. J. and Pienkowski, M. W. (1997) Conclusions: a future for farming and birds? Pp 358-388 in D. J. Pain and M. W. Pienkowski, eds. Farming and birds in Europe. San Diego: Academic Press. 
Pretty, J. (1998) The living land. London: Earthscan.

Shrubb, M. (1988) The influence of crop rotations and field size on a wintering Lapwing Vanellus vanellus population in an area of mixed farmland in West Sussex. Bird Study 35: 123-131.

Tucker, G. M. (1992) Effects of agricultural practices on field use by invertebrate-feeding birds in winter. J. Appl. Ecol. 29: 779-790.

Wakeham-Dawson, A. and Aebischer, N. J. (1998) Factors determining winter densities of birds on Environmentally Sensitive Area arable reversion grassland in southern England, with special reference to Skylarks (Alauda arvensis). Agric. Ecosyst. Environ. 70: 189201.

Wilson, J. D., Taylor, R. and Muirhead, L. B. (1996) Field use by farmland birds in winter: an analysis of field type preferences using resampling methods. Bird Study 43: 320-332.

Wilson, J. D., Evans, J. Browne, S. J. and King, J. R. (1997) Territory distribution and breeding success of Skylarks Alauda arvensis on organic and intensive farmland in southern England. J. Appl. Ecol. 34: 1462-1478.

CHRISTOPHER F. MASON AND SHEILA M. MACDONALD

Department of Biological Sciences, University of Essex, Wivenhoe Park, Colchester $\mathrm{CO}_{4}{ }_{3} \mathrm{SQ}$, U.K. (e-mail:masoc@essex.ac.uk) 